DOI: $10.2478 /$ lpts-2018-0019

PHYSICS

\title{
NONLINEAR THERMODIFFUSION IN GASES AT MODERATE TEMPERATURES
}

\author{
A.J.Janavičius ${ }^{1}$, S.Turskienè ${ }^{2}$ \\ ${ }^{I}$ Šiauliai University, 88 Vilniaus Str., LT-76285, Šiauliai, LITHUANIA \\ e-mail: AYanavy@gmail.com \\ ${ }^{2}$ Computer Science Department, Šiauliai University, 141 Vilniaus Str., \\ LT-76353, Šiauliai, LITHUANIA \\ e-mail: turskienes@gmail.com
}

\begin{abstract}
The paper discusses the properties of the nonlinear thermodiffusion equation corresponding to the diffusion processes, which occur with a finite velocity. In the previous papers, A. J. Janavičius proposed the nonlinear diffusion equation with the diffusion coefficient directly proportional to the concentration of impurities. This equation provides a more exact description of the profiles of impurities in Si crystals. The heat transfer in gases carries a greater average kinetic energy based on nonlinear diffusion of gas molecules from hot regions to the coldest ones with a finite velocity by random Brownian motions. In this case, the heat transfer in gases can be described by using nonlinear thermodiffusion equation with heat transfer and thermodiffusion coefficients directly proportional to temperature $T$. The obtained approximate analytical solutions are successfully applied in defining temperature profiles and heat transfer coefficients in gases as well as providing opportunities for practical applications. It has been concluded that heat spreading in gases depends on temperature differences and pressure in gases.
\end{abstract}

Keywords: approximate analytical solution, nonlinear thermal diffusion equation, temperature profiles

\section{INTRODUCTION}

In the previous papers, we have discussed the nonlinear diffusion of impurities in semiconductors [1], [2], nonlinear thermodiffusion in gasses [3] and heat transfer in metals by electrons [4] using mathematical methods of similarity variables [1] for nonlinear equations. The obtained results are important for engineering applications. We assume that the process of heat transmittance in gasses is similar to nonlinear diffusion processes described as Brownian movement of atoms in solids spreading with a finite velocity. Heat transfer can be described using modified theory of the nonlinear 
diffusion in solids [1]. In this case, the frequency of the jumps of diffusing molecules [6] depends upon the coordinates, concentration and temperature. The coefficient of thermal conductivity of gases can be expressed in the following way [6]:

$$
K=\frac{1}{3} \lambda \bar{v} c_{v} \rho=D_{m} c_{v} \rho=\frac{k \bar{v}}{2 \sqrt{2} \pi d^{2}}, \lambda=\frac{1}{\sqrt{2} \pi d^{2} n}, \bar{v}=\sqrt{\frac{8 R T}{\pi \mu}} .
$$

Here $\lambda$ - mean values of a free path of diffusing molecules, $\bar{v}-$ mean velocities of molecular movement, $c_{v}$ - molar heat capacity at constant volume, $\rho$ - density of gas, $n$ - number of molecules per unit volume, $k$ - Boltzmann constant, $T$ - temperature of gases, $\mu$ - molar mass, $R-$ gas constant, $d-$ diameter of a gas molecule, $D_{m}$ - coefficient of thermal diffusion in gases.

We introduced the equation of thermal conductivity of gases [6] with the nonlinear thermodiffusion coefficient proportional to the temperature:

$$
D_{n}(T)=\frac{K(T)}{\rho \cdot c_{p}}=\frac{K_{e} T}{\rho \cdot c_{p} \cdot T_{e}}=\frac{k \bar{v}}{\sqrt{2} \pi d^{2} p T_{e}} T=\frac{D_{e}}{T_{e}} T(x, t)=D_{e n} T(x, t)
$$

We introduced the constant pressure $p=n(x, t) k T(x, t)$ for slow heat transmission in gases when decreasing temperature $T(x, t)$ is compensated by increasing concentration $n(x, t)$ of gases.

Using the heat flow $j$ for continuity equation [6], we obtained

$$
\frac{\partial T}{\partial t}=-\operatorname{div}\left(-D_{n}(T) \operatorname{grad}(T)\right), j_{p}=-D_{n}(T) \frac{\partial T}{\partial x} .
$$

Here constant $D_{e}$ - thermodiffusion coefficient in environment for the specific heat capacity $c_{p}$ of gases at constant pressure $p, K_{e}$ - coefficient of thermal conductivity of environment, $T_{e}$ - temperature of environment, $D_{e n}$ - proportionality constant for nonlinear thermodiffusion function $D_{n}(T)$.

The nonlinear thermodiffusion equation(3) for temperature $T(x, t) 0 \leq x \leq x_{0}$, $0 \leq t \leq t_{0}$ can be rewritten in a more convenient form

$$
\frac{\partial T}{\partial t}=D_{e n}\left[\frac{\partial}{\partial x}\left(T \frac{\partial T}{\partial x}\right)\right]
$$

which mathematically coincides with nonlinear diffusion equation [1]. The numerical calculations provided in [2] give dependence $n(x, t)$ as a straight line in the region $0 \leq x \leq x_{0}, 0 \leq t \leq t_{0}$ and temperature $T(x, t)$ dependence must be similar. The jump of a greeter kinetic energy of hotter molecules to the points $x+\lambda$ is possible only if it exists in the points $x$. This requirement is equivalent to the approval that thermodiffusion must occur with finite velocity. It is very important for definition of thermal conductivity [3] and diffusion coefficients [1], [2].

The nonlinear heat conduction equation [7] can be rewritten by introducing nonlinear equation 


$$
\frac{\partial E}{\partial t}=\frac{\partial}{\partial x}\left(k_{e}(E) \frac{\partial E}{\partial x}\right)
$$

for energy density $E$.

The complicated approximate analytical solution [7] $E(x, t)$ of the equation (5) cannot be experimentally measured. In our case, temperatures $T(x, t)$ can be measured directly and compared to theoretical calculations.

\section{SOLUTION OF THE NONLINEAR HEAT DIFFUSION EQUATION FOR ONE-DIMENSIONAL CASE}

The solution of (4) can be obtained by introducing similarity variable [5] $\xi$ and function $f(\xi)$

$$
\begin{aligned}
& T(\xi)=T_{e} f(\xi), \quad \xi=\frac{x}{\sqrt{D_{e n} T_{e} \cdot t}}=\frac{x}{\sqrt{D_{e} t}}, \\
& 0 \leq \xi \leq \xi_{0}, 0 \leq x \leq x_{0}, x_{0}=\xi_{0} \sqrt{D_{e n} T_{e} \cdot t}=\xi_{0} \sqrt{D_{e} t},
\end{aligned}
$$

which depends on thermodiffusion constant $D_{e}$ at environment temperature $T_{e}$. By substituting (6) into (4), we obtain nonlinear differential equation

$$
2 \frac{\partial}{\partial \xi}\left(f \frac{\partial f}{\partial \xi}\right)+\xi \frac{\partial}{\partial \xi} f=0 .
$$

The solution of this nonlinear equation can be expanded by power series, including boundary condition at maximum value $\xi=\xi_{0}$

$$
f(\xi)=\sum_{n=0}^{\infty} a_{n}\left(\xi-\xi_{0}\right)^{n}, f(z)=\sum_{n=0}^{\infty} a_{n} z^{n}, \quad z=\xi-\xi_{0},-\xi_{0} \leq z \leq 0 .
$$

Now equation (7) must be transformed for the new variable $z$

$2 \cdot \frac{\partial}{\partial z}\left(f \frac{\partial}{\partial z} f\right)+z \cdot \frac{\partial}{\partial z} f+\xi_{0} \frac{\partial}{\partial z} f=0$.

By requiring that solution $f(z)$ of nonlinear equation (9) can be expressed by power series, we obtain recurrence relations [8] between coefficients $a_{n}, n=0,1,2, \ldots$ (10) 


\section{THE APPROXIMATE ANALYTICAL SOLUTION}

In the approximation by polynomials we used expansion restricted by coefficients $a_{0}, a_{1}, a_{2}, a_{3}$. From expression (10) at $n=0,1,2$ we obtain the following system of equations:

$$
\begin{aligned}
& 4 a_{2} a_{0}+2 a_{1}^{2}+\xi_{0} a_{1}=0, \\
& 12 a_{3} a_{0}+12 a_{2} a_{1}+a_{1}+2 \xi_{0} a_{2}=0, \\
& 24 a_{3} a_{1}+12 a_{2}^{2}+2 a_{2}+3 \xi_{0} a_{3}=0, a_{0}=1,
\end{aligned}
$$

where in (13) $a_{4}=0$. From the boundary condition $T(0)=T_{e} f(0)$ at heat maximum penetration point we obtain $f(0)=a_{0}=1$.

The solution $f(z)$ (8) must satisfy the second boundary condition $T\left(-\xi_{0}\right)=T_{e} f\left(-\xi_{0}\right)=T_{S}$ at heat source $T(\xi=0)=T_{S}$. Then we obtain

$$
\left(T(z)-T_{e}\right) / T_{e}=a_{1} z+a_{2} z^{2}+a_{3} z^{3}, z=\xi-\xi_{0} \cdot
$$

The expression of temperature (6), (8) at heat source $T_{S}$ is obtained

$$
T=T_{e} f\left(-\xi_{0}\right)=T_{S}, \sum_{m=1}^{n+1}(-1)^{m} a_{m} \xi_{0}^{m}=\frac{\Delta T}{T_{e}}, \Delta T=T_{S}-T_{e} .
$$

The approximate solution

$$
f_{3}(z)=a_{0}+a_{1} z+a_{2} z^{2}+a_{3} z^{3}, a_{0}=1
$$

is used including the boundary condition (15)

$$
-a_{3} \xi_{0}{ }^{3}+a_{2} \xi_{0}^{2}-a_{1} \xi_{0}=\frac{T_{S}}{T_{e}}-1, \frac{T_{S}}{T_{e}}-1=\frac{T_{S}-T_{e}}{T_{e}}=\frac{\Delta T}{T_{e}} .
$$

Thermodiffusion coefficients $D_{e}=K_{e} /\left(\rho \cdot c_{p}\right)$ and experimental [9] values of heat conductivities $K_{e}$ in air at normal pressure $p=1.013 \cdot 10^{5} \mathrm{~N} / \mathrm{m}^{2}$ and moderate temperatures with specific heat $c_{p}=0.999 \cdot 10^{3} \frac{\mathrm{J}}{\mathrm{kg} \cdot \mathrm{K}}$ for air density
$\rho=1.293 \mathrm{~kg} / \mathrm{m}^{3}$ are presented in Table 1 . 
Dependence of Heat Conductivity $K_{e}$ and Thermodiffusion $D_{e}$ Coefficients at Temperatures $t^{\circ} \mathrm{C}$

\begin{tabular}{|c|c|c|c|}
\hline$t^{\circ} \mathrm{C}$ & $T, K$ & $K_{e}, \frac{10^{-2} \mathrm{~J}}{\mathrm{smK}}$ & $D_{e}, 10^{-2} \frac{\mathrm{m}^{2}}{\mathrm{~s}}$ \\
\hline 27 & 300.15 & 2.553 & 2.172 \\
\hline 17 & 290.15 & 2.485 & 2.043 \\
\hline 7 & 280.15 & 2.417 & 1.919 \\
\hline-3 & 270.15 & 2.348 & 1.798 \\
\hline-23 & 250.15 & 2.207 & 1.565 \\
\hline-53 & 220.15 & 1.983 & 1.237 \\
\hline
\end{tabular}

Using these meanings of $D_{e}$ and solving (11), (12), (13), (17), we can obtain the heat penetration depths (6) $x_{0}=\xi_{0} \sqrt{D_{e} t}$ and profiles (14) for temperature differences $\left(T(\xi)-T_{e}\right) / T_{e}$. The coefficients $a_{1}, a_{2}, a_{3}, \xi_{0}$ defining solution (16) $f(z)$ are presented in Table 2.

Using solutions (16) presented in Table 2, we see that at less values $\Delta T / T_{e}$ they can by simplified by taking $a_{2} \xi_{0}{ }^{2} \approx 0$ and $a_{3} \xi_{0}{ }^{3} \approx 0$. In this case, the parameter $\xi_{0}=-\frac{1}{a_{1}}\left(T_{S}-T_{e}\right) / T_{e}$ can be obtained from (17). The constants $a_{1}, a_{2}$ practically are not changing at different $\Delta T / T_{e}$. The solutions for $t^{0} C=-53{ }^{0} C$ in two last rows of Table 2 practically coincide. This means that approximate solution with $a_{3}=0$ presented in the last row is sufficiently exact for practical calculations. The constant $\xi_{0}$, defining a maximum of heat penetration depths $x_{0}$ proportional to $\sqrt{D_{e}} t$ like for nonlinear diffusion [1], can be expressed approximately

$$
x_{0}=\xi_{0} \sqrt{D_{e}} t, \quad \xi_{0} \approx-\frac{1}{a_{1}}\left(T_{S}-T_{e}\right) / T_{e}
$$

for $x_{0}, \xi_{0}$ that is directly proportional to the $\Delta T$ like for the introduced amount of heat quantity [6]. When the temperature of environment is $T_{e}$, where $x_{0}$ is directly proportional to the square root of heat spreading time $t$ like for nonlinear diffusion case [1], we used relation $\Delta T / T_{e}$ for the temperature of environment $T_{e}$ and the normal room temperature $T_{S}=293.15 K$ representing the constant source.

The obtained solutions of equation (9) are presented in Table 2. The experimental heat penetration depths can define thermal diffusion coefficients $D_{e}$ with dimension $m^{2} s^{-1}$. In this way, the dependence of $D_{e} T / T_{e}$ on temperature at constant pressure (2) $p$ can be used. We can find a sufficiently exact solution of the system of equations (11), (12) and (13), when $a_{4}=0$ and the boundary condition (15) is as follows:

$$
-a_{3} \xi_{0}^{3}+a_{2} \xi_{0}^{2}-a_{1} \xi_{0}=\frac{\Delta T}{T_{e}}, \Delta T=T_{S}-T_{e} .
$$

The sufficiently exact solutions $f(z)$ calculated by Mathcad 2013 are presented in Table 2 . 
The Dependence of Parameters $a_{1}, a_{2}, a_{3}, \xi_{0}$ for

Approximate Solution $f(z)$ on $\Delta T / T_{e}$, when $T_{S}=295,15 \mathrm{~K}$

\begin{tabular}{|c|c|c|c|c|c|c|c|}
\hline$t_{e}{ }^{0} C$ & $T_{e} K$ & $\Delta T / T_{e}$ & $\xi_{0}$ & $a_{1}$ & $a_{2}$ & $a_{3}$ & $\Delta T /\left(T_{e} \xi_{0}\right)$ \\
\hline 17 & 290.15 & 0.0172 & 0.041 & -0.422 & -0.085 & -0.0083 & 0.4195 \\
\hline 7 & 280.15 & 0.0535 & 0.122 & -0.449 & -0.087 & -0.0080 & 0.4385 \\
\hline-3 & -270.15 & 0.0925 & 0.202 & -0.477 & -0.090 & -0.0076 & 0.4579 \\
\hline-23 & $-250,15$ & 0.180 & 0.360 & -0.533 & -0.094 & -0.0070 & 0.500 \\
\hline-53 & -220.15 & 0.3407 & 0.604 & -0.622 & -0.099 & -0.0061 & 0.5641 \\
\hline-53 & -220.15 & 0.3407 & 0.606 & -0.623 & -0.099 & 0.0000 & \\
\hline
\end{tabular}

The profiles of functions $f_{i}$ and $F_{i}(14)$ like $\left(T(\xi)-T_{e}\right) / T_{e}$ for heat source temperature $T_{S}=295.15 \mathrm{~K}$ and the environment temperatures $-3,-23 t_{e}{ }^{0} \mathrm{C}$ and $-23,-53 T_{e}{ }^{0} C$ are presented graphically using Mathcad 2013 in Fig. 1 and Fig. 2, respectively.

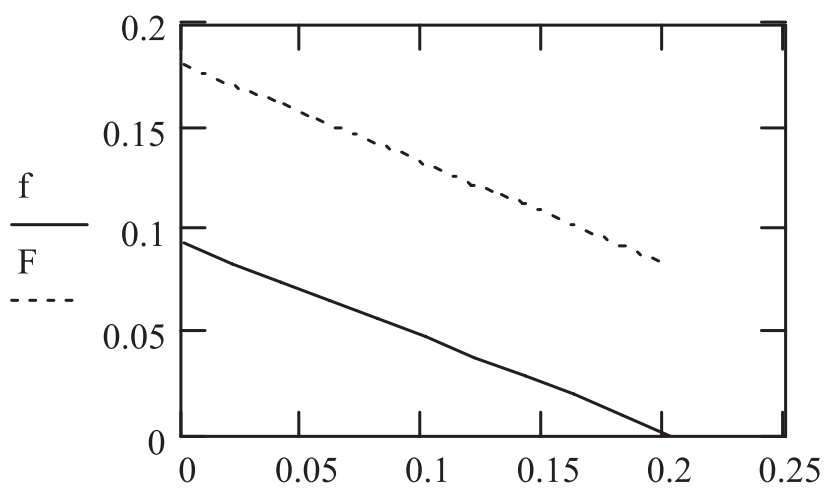

Fig. 1. Profiles of functions $f(z=\xi)$ and $F(z=\xi)$ presenting relative differences $\left(T(\xi)-T_{e}\right) / T_{e}$ of source $T_{S}=295.15 \mathrm{~K}$ and environment temperatures respectively $T_{e}=-3,-23{ }^{0} \mathrm{C}$.

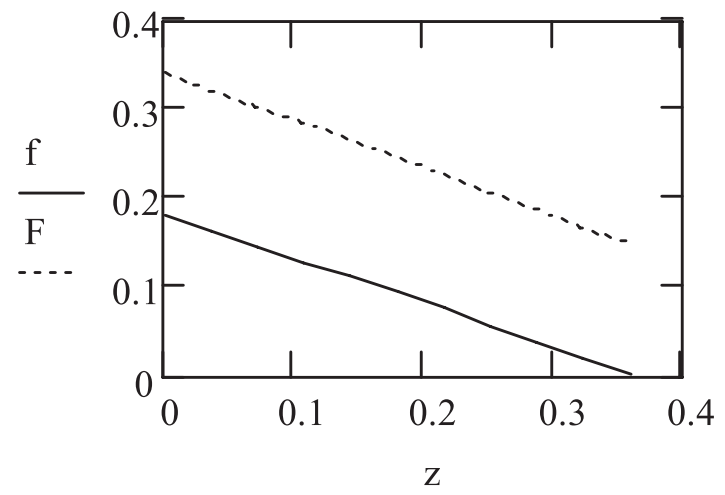

Fig. 2. Profiles of functions $f(z=\xi)$ and $F(z=\xi)$ representing relative differences $\left(T(\xi)-T_{e}\right) / T_{e}$ of source $T_{S}=295.15 \mathrm{~K}$ and environment temperatures respectively $t_{e}=-23,-53{ }^{0} \mathrm{C}$. 
The profiles in Fig. 1 and Fig. 2 are parallel lines, which are defined by $\Delta T /\left(T_{e} \xi_{0}\right)$ and relations

$$
\Delta T /\left(T_{e} \xi_{0}\right)=C\left(T_{S}, T_{e}\right)
$$

presented by slowly changing numbers $C\left(T_{S}, T_{e}\right)$ in Table 2 . The form of the obtained profiles approximately coincides with the profiles of nonlinear diffusion in solids when the diffusion coefficient is directly proportional to concentration of impurities for temperature depending on time [10]. The quantity of the heat $Q_{S}$ introduced in gases from surface with square $S$ can be equally transmitted to gasses

$$
Q_{S}=K(T) \cdot S \frac{T_{S}-T_{e}}{x_{0}} t, Q_{p}=0.5 \cdot c_{p} \bar{\rho} V \Delta T=0.5 \cdot c_{p} \bar{\rho} \Delta S \cdot \Delta T \cdot x_{0}
$$

The obtained result is similar to the quantity of the introduced impurities by the nonlinear diffusion [11] when impurity concentration $N_{S}$ at the crystal surface stays constant

$$
Q=0.5492 N_{S} x_{0}
$$

In the nonlinear thermodiffusion model, heat transition by the molecules with large $\Delta T / T_{e}$ and significantly greater average kinetic energy such as diffusion of some impurities in cold gases can be considered. The heat spreading from a point source with heat quantity $Q$ in a one dimensional case in $x$ axis is presented by changing of temperatures [12] and defined by $\sqrt{D_{S} t}$

$$
T(x, t)-T_{S}(0,0)=\frac{Q}{\rho_{l} c \sqrt{\pi 4 D_{S} t}} \exp \left(-x^{2} / 4 D_{S} t\right)
$$

at linear material density $\rho_{l}$ with specific heat $c$. Here, as in (21) the transferred heat quantity $Q$ from the point source at $x=0$ is approximately proportional to square root of time at the distance $x<2 \sqrt{D_{S} t}$. This result is similar to the results obtained in [1] where linear diffusion profiles are small at the region $x \approx x_{0}$ for nonlinear diffusion.

\section{RESULTS AND CONCLUSIONS}

A similar task and approach have been considered for nonlinear diffusion [2], [13], [14] in gases. In this case, the definition of diffusion coefficients, which depend on average values of frequencies of molecule collisions in the frontier region of diffusion profiles, has been introduced. For practical calculations of temperature profiles, the coefficients $a_{1}, a_{2}, a_{3}$ at small $\Delta T / T_{e}=0.02,0.5,0.1$ are sufficiently exact (19) and approximately coincide with coefficients of solution of nonlinear dif- 
fusion equation [11]. For these values of $\Delta T / T_{e}$ the average meaning of $\bar{v}$ for approximate (2) $D_{e} T / T_{e}$ evaluation can be used. For definition of $D_{e} T / T_{e}$ value dependence on temperatures and pressures, the values $a_{1}, a_{2}, a_{3}$, presented in Table 2 at $\Delta T / T=0.05$, can be used. By the convergence of the obtained values $a_{1}, a_{2}, a_{3}$ presented in Table 2, we get that for a case of maximum values $\Delta T /\left(T_{e} \xi_{0}\right)$ the constants $a_{1}, a_{2}$ practically coincide (19) when we take $a_{3}=0$. The results presented in Table 2 show that heat penetration depths $x_{0}$ and $\xi_{0}$ (17) are approximately proportional to $\Delta T / T_{e}$ values. In the case of nonlinear heat conductivity (4), we obtained like in the Fourier's law of heat conduction (21) that the transmitted heat quantity is proportional to $\Delta T$. It is very important for practical applications of measured values $T\left(x \geq x_{0}\right)=T_{e}, x_{0}, \Delta T$ and analytical solutions (19) for definition of $D_{e}$. Using (21) $Q_{S}$ we can find temperature of source $T_{S}$ when measurements are hard, for example, walls and windows of buildings. Using (21) $x_{0}=\xi_{0} \sqrt{D_{e}} t, D_{e}$ we can obtain

$$
Q_{S}=\bar{K} \cdot S\left(T_{S}-T_{e}\right) \frac{x_{0}}{D_{e} \xi_{0}^{2}}
$$

transmitted heat $Q_{S}$ by surface $S$ for definition of heat conductivity $\bar{K}$ from measurements $\Delta T, x_{0}, T_{S}, T_{e}$, calculated (19) $\xi_{0}$ and Table 1 .

\section{REFERENCES}

1. Janavičius, A.J. (1997). Method for solving the nonlinear diffusion equation. Physics Letters A, 224, 159-162.

2. Janavičius, A.J., \& Turskienè, S. (2016). Nonlinear thermal conductivity in gases. Proc. of the Lithuanian Mathematical Society, Ser. A, 57, 21-28, DOI: 10.15388/ LMR.A.2016.05

3. Janavičius, A.J., \& Turskienè, S. (2006). Modeling of thermodiffusion inertia in metal films heated with ultrashort lasers pulses. Acta Phys. Pol. A, 110, 511-521.

4. Rudakov, V.I ., \& Ovcharov V. V. (2001). Mathematical description of the diffusion a temperature field and measuring the heat of transport, International Journal of Heat and Mass Transfer, 45, 743-753.

5. Joos, G., \& Freeman, I.M. (1986). Theoretical physics. New York: Dover Publications, Inc.

6. Janavičius, A.J., \& Poškus, A. (2005). Nonlinear diffusion equation with diffusion coefficient directly proportional to concentration of impurities. Acta Phys. Pol. A, 107, 519-521.

7. Yu, J., Yang, Y., \& Campo, A. (2010). Approximate solution of the nonlinear heat conduction equation in a semi-infinite domain. Mathematical Problems in Engineering, 2010, Article ID 421657. DOI:10.1155/2010/421657.

8. Filchakov, P. F. (1973). Handbook of high mathematics. Kiev: Scientific Thought (in Russian).

9. Goldin, L.L. (1983). Laboratory works in physics. Novosibirsk: Science (in Russian). 
10. Janavičius, A.J. (1997). Nonlinear diffusion in excited systems. Lithuania Journal of Physics, 37(6), 508-510.

11. Janavičius, A.J. (1998). Nonlinear many-staged diffusion. Acta Phys. Pol. A, 93, 731735.

12. Knoibiul, F.K. (1981). Handbook for repeating of physics. Moscow: Energoizdat (in Russian).

13. Apostol, B.F. (1997). On a non-linear describing clouds and wreaths of smoke. Phys. Lett. A, 235, 363-366.

14. Janavičius, A.J., Lūža G., \& Jurgaitis, D. (2004). The nonlinear diffusion equation describing spread of impurities of high density. Acta Phys. Pol. A, 107, 475-483.

\title{
NELINEĀRĀ TERMODIFŪZIJA GĀZĒES, ESOT VIDĒJĀM TEMPERATŪRĀM
}

\author{
A.J. Janavičius, S. Turskienè \\ Kopsavilkums
}

Rakstā tiek analizētas nelineārās termodifūzijas vienādojuma īpašības, kas apraksta difūzijas procesus, kuri notiek galīgā ātrumā. Agrākajos darbos prof. A. J. Janavičius ir piedāvājis nelineāro difūzijas vienādojumu ar difūzijas koeficientu, kas ir tieši proporcionāls piemaisījumu koncentrācijai. Šis vienādojums precīzāk raksturo $S i$ kristālu piemaisījumu profilus.

Siltuma pārnese gāzēs var notikt ar lielāku vidējo kinētisko enerǵiju, jo nelineārās difūzijas gāzes molekulas no karstām zonām nonāk aukstākās tāpēc, ka nejaušas Brauna daļiņas pārvietojas ar galīgu ātrumu. Šajā gadījumā siltumpārnese gāzēs var tikt aprakstīta ar nelineārās termodifūzijas vienādojumu, kur siltumpārneses un termodifūzijas koeficienti ir tieši proporcionāli temperatūrai $T$. Iegūtie aptuvenie nelineārās termodifūzijas vienādojuma atrisinājumi veiksmīgi tiek izmantoti, lai definētu temperatūras profilu un siltumpārneses koeficientu gāzē. Darba rezultāti liecina, ka siltuma izplatīšanās gāzēs ir atkarīga no temperatūru starpības un gāzes spiediena.

23.03.2018. 